\title{
Financial Ratio, Macro Economy, and Investment Risk on Sharia Stock Return*
}

\author{
Bambang WIDAGDO ${ }^{1}$, M. JIHADI ${ }^{2}$, Yanuar BACHITAR ${ }^{3}$, Oky Ervina SAFITRI ${ }^{4}$, Sanju Kumar SINGH ${ }^{5}$
}

Received: September 01, 2020 Revised: October 26, 2020 Accepted: November 16, 2020

\begin{abstract}
The purpose of this study is to analyze and test the effect of financial ratios and macroeconomics on Islamic stock returns listed in Jakarta Islamic Index (JII) other than to assess whether investment risk can be an intervening variable in this study. The type of research is explanatory in nature with a quantitative descriptive approach. The data used is based on secondary sources with a sample group of 29 companies listed on JII for a 5-year period ending 31 December 2018. The data obtained were analyzed by using SEM (Structural Equation Model) with AMOS (Analysis Moment of Structural) 21 program. The results of the study show that only financial ratios affect sharia stock returns and investment risk, while the mediation test found that investment risk does not act as a mediating variable between financial ratios and macroeconomics and Islamic stock return. These findings indicate that the role of the company's financial health is very important. Besides affecting the rate of return obtained, the company's financial health can also reflect the level of risk that investors will accept in the future. By improving financial performance properly, a company will have a positive impact on various interested parties and minimize the level of investor losses.
\end{abstract}

Keywords: Financial Ratios, Macroeconomics, Investment Risk, Sharia Stock Returns

JEL Classification Code: G10, G20, G30, G40

\section{Introduction}

Indonesia is a mecca for the development of Islamic finance of global players in the world, this can be seen from the size of the Muslim population, which reached $87 \%$ of the

\footnotetext{
*Acknowledgments:

There is not any conflict of interest among all of authors.

${ }^{1}$ First Author. Professor, Faculty of Economics and Business, Universitas Muhammadiyah, Malang, Indonesia. Email: bwidagdo@umm.ac.id

'2Lecturer, Faculty of Economics and Business, Universitas Muhammadiyah, Malang, Indonesia. Email: jihadi@umm.ac.id

${ }^{3}$ Associate Professor, Sekolah Tinggi Ilmu Ekonomi Indonesia, Banjarmasin, Indonesia.

Email: yanuarbachtiar@stiei-kayutangi-bjm.ac.id

${ }^{4}$ Faculty of Economics and Business, Universitas Muhammadiyah, Malang, Indonesia. Email: okyervinasafitri@webmail.umm.ac.id ${ }^{5}$ Corressponding Author. Doctoral Student, Department of Management, Faculty of Economics and Business, Universitas Airlangga, Surabaya, Indonesia [Postal Address: Jl. Airlangga No.4 - 6, Airlangga, Kec. Gubeng, Kota SBY, Jawa Timur 60115, Indonesia] Email: sanju.kumar.singh-2017@feb.unair.ac.id

(c) Copyright: The Author(s)

This is an Open Access article distributed under the terms of the Creative Commons Attribution Non-Commercial License (https://creativecommons.org/licenses/by-nc/4.0/) which permits unrestricted non-commercial use, distribution, and reproduction in any medium, provided the original work is properly cited.
}

237.6 million people in the population census by the Central Statistics Agency (BPS) in 2010. This is evidenced by the achievement of Indonesia's first ranking in Global Islamic Finance Report (GIFR) 2019 with Islamic stock capitalization reaching Rp.3,700 trillion in June 2019. This top ranking is an acknowledgment of all parties, including business actors, academics, government and society in realizing the Master Plan for Sharia Economics (MEKSI) and the Master Plan for Islamic Finance Architecture (MAKSI) to enhance the role of Islamic finance (bappenas.go.id, 2019).

Sharia stock investment in Indonesia has developed quite rapidly, as recorded in the 2018 Indonesian Sharia Financial Development Report by the Otoritas Jasa Keuangan (OJK); the growth of investors in sharia securities investment increased by 401,516 investors or the equivalent of growing $38.16 \%$ compared to previous years. This indicates that Islamic stocks are starting to attract investors. on the other hand, returns on Islamic equity are bigger than the return from conventional equity (Al-Yahyaee, 2020). Stocks are one of the investment instruments that fluctuate and tend to have a high level of risk, but this does not make investors shy away from buying and selling shares in the capital market, because investors have high expectations of the risks faced with the returns they will get in the future. 
Return is one of the factors that can motivate investors to interact in the investment world and is also a reward for their courage to take risks with their investment (Tandelilin, 2010). According to Ang (1997) there are two things that affect the return on investment, including internal and external factors. Internal factors including the quality of a company's management, the composition of company assets, the ratio between assets, and the debt itself. The company's external factors include monetary and fiscal policy, inflation, interest rates, exchange rates, and so on.

According to Thampanya (2020), the fundamental or internal factors of a company have an important role in influencing the volatility of the stock market. Internal factors in a company can be seen from their financial ratios, such as profitability ratios, solvency, liquidity, activity, and market ratios. In this study, researchers will use Return On Asset (ROA) to see the profitability ratio, Debt-to-Equity Ratio (DER) for solvency ratio, Current Ratio (CR) for liquidity ratio, Total Asset Turnover (TATO) for activity ratio, and Earning Per Share (EPS) for the market ratio.

Kurniawan and Yusra (2019), Aryanti and Mawardi (2016), Marito and Sjarif (2020) in their research found that the profitability ratio partially has a positive effect on sharia stock returns, in contrast to Latifah (2020), Arif (2020) who found the ratio profitability has no effect on stock returns. Furthermore, the solvency ratio in the research by Roslianti and Herlambang (2015), Arif (2020) found that DER partially has no effect on stock returns. In contrast to Latifah (2020), Nurhikmawaty (2020) dan Suciati (2018) found that the solvency ratio has a significant effect on stock returns.

The liquidity ratio with the CR measurement variable from Rizal (2016), Suciati (2018) and Latifah (2020) found that partially $\mathrm{CR}$ has no effect on stock returns. Aryanti and Mawardi (2016) revealed that CR has a negative and significant effect on sharia stock returns in JII, in contrast to Singa et al. (2020) who found that CR has a positive and significant effect on stock returns. For Rahman [15] the liquidity ratio partially affects the return of Islamic stocks in JII.

Pratama and Idawati (2019), Singa et al. (2020), in their research on activity ratios, found that TATO simultaneously and partially had a positive and significant effect on sharia stock returns in JII. In contrast, Indiyani's (2020) research found that TATO had no effect on stock returns, similar to Rahman (2014) who found that the activity ratio had no effect on sharia stock returns in JII. Furthermore, Supadi and Amin (2016) found that EPS as a measurement variable in market ratios has an effect on sharia stock returns partially and simultaneously. This is in contrast to Latifah (2020) and Purbawangsa (2020) who found that EPS has no effect on stock returns.

External factors, called macroeconomics in this study, are important factors for investors, because any changes can affect investment, especially on stock returns themselves. Macroeconomic factors used in this study are interest rates, inflation, and exchange rates. Andyani and Mustanda (2018) found a significant influence between macroeconomics and sharia stock returns, like Mensi (2017). Mawarni and Widiasmara (2018) found that SBI has a negative and significant effect on sharia stock returns in Indonesia. In contrast to Artaya (2014) who found that interest rates have a positive and significant effect on stock returns.

Suyati (2016) and Perkasa (2019) found that inflation has a significant effect on stock returns. Suciningtias and Khoiroh (2015) found that inflation has a negative and significant effect on sharia stock returns. Mawarni and Widiasmara (2018) found that inflation does not have a significant effect on the Islamic stock index. Researching exchange rate variables, Suyati (2016), Indriastuti and Nafiah (2017) found that the exchange rate has a negative effect on Islamic stock returns. This is different from Abi Nugroho and Hermuningsih (2020) who found that the exchange rate has a positive effect on stock returns.

Given the explanation above, there are research gaps related to financial ratio, macroeconomics and investment risk factors on sharia stock returns, so we will contribute research on this problem by using some of the above variables in the context of Islamic stock investment listed in JII.

\section{Literature Review}

\subsection{Signaling Theory}

Signaling theory is a theory that discusses how signals relating to the success and failure of management are conveyed to investors (Farhana \& Adelina, 2019). The signal that is conveyed is in the form of a financial report or annual report by management as a form of information, whether it has done something in accordance with the provisions and the contract or not (Wijaya, 2020).

This will also be done by a company to provide information to investors by publishing financial reports or annual reports as a tool used to attract investors. A good and positive signal is a reflection that the company has experienced growth and improvement in terms of income in the industrial world and this will be informed to investors through the company's financial statements.

\subsection{Stock Return}

Stock return is the level of profit an investor receives and enjoys on his stock investment, because basically investment activities in long-term and short-term purchases have the main objective to generate profits, which are also called stock returns, either directly or indirectly (Ang, 1997). 
There are two kinds of returns received by shareholders, namely, dividends and changes in stock prices during a period or what is known as capital gains (idx.co.id, 2018). On the other hand, there is the related return, which is the return obtained based on the historical data of a company, which can describe the company's performance, and this historical return can also be used as a basis for determining the expected return, while the expected return is the return expected to be obtained by investors in the future (Erari, 2014).

For Ang (1997) there are two things that affect the return of investment - internal and external factors; internal factors including the quality of management of a company, the composition of company assets, the ratio between assets, and the debt itself. External factors include monetary and fiscal policy, inflation, interest rates, exchange rates, and so on.

\subsection{Financial Ratio to Sharia Stock Return}

Paying attention to financial ratios to determine investment is needed by an investor. Tran, Nguyen, and To (2020), Rizal (2016), and Erzad (2017) found that the profitability ratio partially has a positive effect on the return of sharia securities. Solvency ratios in the research by Dita and Murtaqi (2014), Felicia (2019), Roslianti and Herlambang (2015) found that DER simultaneously affects sharia stock returns.

The liquidity ratio, partially has an effect on the return of Islamic stocks in JII (Rahman, 2014). Pratama and Idawati (2019), Singa et al. (2020) Indiyani (2020) found that TATO simultaneously and partially has a positive and significant effect on stock returns. Felicia (2019), Supadi and Amin (2016) found that EPS as a measurement variable in market ratios has an influence on Islamic stock returns.

\subsection{Macroeconomics against Sharia Stock Returns}

Macroeconomics has an important role in capital market activities, especially in the volatility of stock market profit (Abbas, 2019) although for some condition, macroeconomics has a negative relationship with stock market (Lee \& Brahmasrene, 2020). The exchange rate is the value relationship between a unit of domestic currency and the foreign currency or the value of a country's currency against the currencies of other countries used in trade transactions, where the value of the currency is influenced by the supply and demand for the currency of the country concerned (Artha, 2014). Nguyen, Nguyen and Nguyen (2020) showed that exchange rate has no consistent effect on stock market. Yusfiarto and Pambekti (2020b), Suyati (2016), Indriastuti and Nafiah (2017) found that the exchange rate has a negative effect on Islamic stock returns.

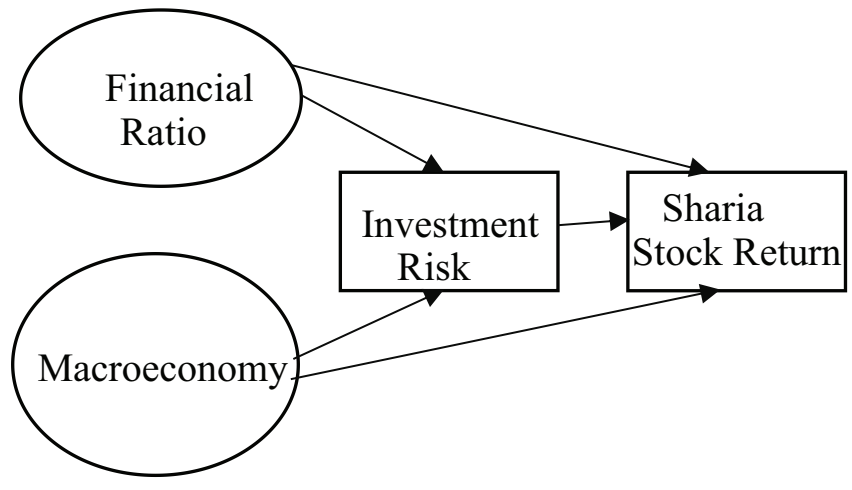

Figure 1: Research Empirical Model

Suciningtias and Khoiroh (2015), Mawarni and Widiasmara (2018), Yusfiarto and Pambekti (2020a) showed that high inflation will result in a decrease in stock prices due to an increase in the price of goods in general; this affects the production costs and the higher the selling price of goods, the higher the decrease in people's purchasing, so that it will affect company profits. Yusfiarto (2020), Jamaludin (2017), Suciningtias and Khoiroh (2015) state that inflation has a negative and significant effect on sharia stock returns. BI 7-Day Repo Rate is the benchmark interest rate announced by Bank Indonesia as a response to monetary policy, and changes in interest rates can usually affect the variability of returns on investment (Farida \& Darmawan, 2017). Hernowo (2020), Habib and Islam (2017), Mawarni and Widiasmara (2018) found that the interest rate has a negative and significant effect on the return of Islamic stocks in Indonesia. The following hypotheses are formulated:

\section{H1: Investment risk affects Islamic stock returns}

H2: Financial ratios have an effect on sharia stock returns

H3: Macroeconomics has an effect on Islamic stock returns

H4: Financial ratios have an effect on investment risk

H5: Macroeconomics affects investment risk

H6: Financial ratios have an effect on Islamic stock returns through investment risk

H7: Macroeconomics affects the returns of Islamic stocks through investment risk

\section{Research Methodology}

The type of research used here is explanatory research. The population used in this study is Islamic stocks are included in the Jakarta Islamic Index (JII) group, while the sample selection uses the purposive sampling method, with the criteria being: Islamic stocks that are actively traded on the stock exchange 
until 2018, Islamic stocks are listed in the JII group, Islamic stocks that have published annual reports for 5 years, namely 2014-2018 (31 December 2018 period). The data source used in this study is secondary data obtained from www.ojk.go.id and www.idx.co.id. The data analysis method used in this research is the SEM (structural equation model) analysis method with the AMOS (Analysis Moment of Structural) program.

\section{Results and Discussion}

Below are the results of the research and the stages of data analysis using SEM and AMOS.

\subsection{Sample Feasibility Test}

Based on the sample criteria in this study, of the 30 companies registered in JII, 29 companies meet the predetermined sample criteria. Data obtained from 29 companies registered in JII totaled 145 samples and have met the standard criteria for the maximum likelihood estimation technique.

\subsection{Outlier Test}

The first outlier test was carried out by looking at the Mahalanobis distance value on the data output in Amos provided that the value of $\mathrm{p} 1$ and $\mathrm{p} 2<0.05$ was said to be the outlier observation (Ferdinan, 2000). The second stage of outlier test looks at the $\mathrm{z}$-score value, a value with a range of 3-4 or $>3.0$ is categorized as an outlier (Hair et al., 2010). Table 1 shows the stages in data processing.

Based on the table above, the researcher tested the data in three stages, then the original data amounted to 145 after deducting outliers to the third stage to 103 samples.

\subsection{Normality Test}

The data normality test is carried out by looking at the critical ratio (CR) value on skewness and curatorial (Minto, 2016), Table 2 shows the normality test results using AMOS:

The table above shows that only the variables $\mathrm{Y}, \mathrm{Z}$ and $\mathrm{X} 1.1$ are normally distributed, while the multivariate shows that the data can be normally distributed with a value of 1,270 or $<2.58$; it can be concluded that the data used in the study are normally distributed and meet the requirements of the normality test.

\subsection{Multicollinearity and Singularity Test}

Below is the multicollinearity and singularity test results detected from the AMOS output show that determinant value of sample covariance matrix is 0.359 or far from zero; it can be concluded that the research data used did not detected multicollinearity and singularity.
Table 1: Data Processing Stages

\begin{tabular}{|l|c|c|c|}
\hline Tahapan & $\begin{array}{c}\text { Jumlah } \\
\text { Data }\end{array}$ & $\begin{array}{c}\text { Data } \\
\text { Outlier }\end{array}$ & Ket. \\
\hline 1 & 145 & 13 & \\
\hline 2 & 132 & 29 & \\
\hline 3 & 103 & - & Normal \\
\hline
\end{tabular}

Table 2: Normality Test

\begin{tabular}{|c|c|c|c|}
\hline \multirow[b]{2}{*}{ Variable } & \multicolumn{2}{|c|}{ Tahap 3 (109) } & \multirow[b]{2}{*}{ Ket. } \\
\hline & $\begin{array}{c}\text { c.r } \\
\text { skew }\end{array}$ & c.r kurtosis & \\
\hline $\mathrm{Y}$ & 1.409 & 0.329 & Normal \\
\hline Z & 0.941 & 0.022 & Normal \\
\hline $\mathrm{X} 1.1$ & 2.760 & 2.568 & Normal \\
\hline $\mathrm{X} 1.2$ & 3.357 & 0.969 & Abnormal \\
\hline $\mathrm{X} 1.3$ & 3.121 & -0.199 & Abnormal \\
\hline $\mathrm{X} 2.1$ & -0.524 & -3.478 & Abnormal \\
\hline $\mathrm{X} 2.2$ & 1.021 & -3.889 & Abnormal \\
\hline $\mathrm{X} 2.3$ & -0.070 & -3.478 & Abnormal \\
\hline Multivariate & \multicolumn{2}{|c|}{1.270} & Normal \\
\hline
\end{tabular}

\subsection{Confirmatory Factor Analysis (CFA) Test}

Confirmatory Factor Analysis (CFA) test was carried out using AMOS with the data after the outlier. Table 3 shows the results of Confirmatory Factor Analysis (CFA).

Based on the table above, the indicators X1.4 and X1.5 must be removed because the factor loading value is below 0.5 , so it cannot be used for data analysis in this study. Meanwhile, other indicators are above 0.5 , which means that it can be used as a measurement variable in this study.

\subsection{Structural Model Test}

The next stage is the model suitability test (Goodness of Fit) using AMOS; the results are presented in Table 4.

The table above shows that the overall model used in the study is acceptable as the output has met the requirements for the goodness of fit index and can be used as the basis for this study.

\subsection{Hypothesis Testing}

\section{a. Direct Effect Hypothesis Test}

Based on the results of the structural model analysis using AMOS, Table 5 shows the results of the hypothesis tests. 
Table 3: Confirmatory Factor Analysis (CFA)

\begin{tabular}{|l|c|c|c|}
\hline Variable & $\begin{array}{c}\text { Loading } \\
\text { Factor } \\
\text { (Stage 1) }\end{array}$ & $\begin{array}{c}\text { Loading } \\
\text { Factor } \\
\text { (Stage 2) }\end{array}$ & Ket. \\
\hline \multicolumn{4}{|c|}{ Financial Ratio } \\
\hline X1.1 & 0.64 & 0.50 & Valid \\
\hline X1.2 & 0.63 & 0.62 & Valid \\
\hline X1.3 & -0.83 & -0.96 & Valid \\
\hline X1.4 & 0.44 & - & Invalid \\
\hline X1.5 & 0.37 & - & Invalid \\
\hline & Macroeconomy & Valid \\
\hline X2.1 & 0.86 & 0.86 & Valid \\
\hline X2.2 & 1.00 & 1.00 & Valid \\
\hline X2.3 & 0.91 & 0.91 & \\
\hline
\end{tabular}

Table 4: Goodness of Fit Index for Structural Model

\begin{tabular}{|l|c|c|c|}
\hline $\begin{array}{l}\text { Goodness of } \\
\text { Fit Index }\end{array}$ & Cut off Value & Result & Ket. \\
\hline Chi Square & 26.30 & 7.681 & Good \\
\hline Probability & $\geq 0,05$ & 0.936 & Good \\
\hline RMSEA & $\leq 0,08$ & 0.000 & Good \\
\hline GFI & $\geq 0,90$ & 0.982 & Good \\
\hline AGFI & $\geq 0,90$ & 0.982 & Good \\
\hline CMIN/DF & $\leq 2,00$ & 0.512 & Good \\
\hline TLI & $\geq 0,90$ & 1.034 & Good \\
\hline CFI & $\geq 0,90$ & 1.000 & Good \\
\hline
\end{tabular}

Table 5: Hypothesis Test Results

\begin{tabular}{|l|c|c|c|c|}
\hline & Koefisien & S.E & C.R & P \\
\hline Hypothesis 1 & .020 & .029 & .198 & .843 \\
\hline Hypothesis 2 & .236 & .049 & 2.209 & .027 \\
\hline Hypothesis 3 & .010 & .004 & .101 & .920 \\
\hline Hypothesis 4 & -.230 & .163 & -2.215 & .027 \\
\hline Hypothesis 5 & .023 & .014 & .234 & .815 \\
\hline
\end{tabular}

Table 6: Sobel Test

\begin{tabular}{|l|c|c|c|}
\hline & $\begin{array}{c}\text { Tes } \\
\text { Statistic }\end{array}$ & Std. Error & $\boldsymbol{P}$-Value \\
\hline Hypothesis 6 & -0.619 & 0.007 & 0.535 \\
\hline Hypothesis 7 & 0.628 & 0.0007 & 0.529 \\
\hline
\end{tabular}

Based on the results of the hypothesis test above, only hypotheses 2 and 4 can be accepted as they have a significant effect. Financial ratios have an effect on sharia stock returns with a beta coefficient of 0.236 and a p-value of 0.027 $(p<0.05)$, then the hypothesis is accepted, that is, there is a positive and significant influence of financial ratios on sharia stock returns. This means that the better the financial ratio of a company, the greater the increase of returns of Islamic stocks. These results are in line with research by Singa et al. (2020), Felicia (2019), Hidayat (2019), Pratama and Idawati (2019), Aryanti and Mawardi (2016), which found that financial ratios have a positive influence and significant to the return of Islamic stocks.

Using fundamental analysis in analyzing stock returns, one of which is by looking at the company's profitability ratio, the more the company can generate high profits, the more it will guarantee an increase in stock returns for each period. Likewise, with the liquidity ratio, the greater the ratio between the assets owned and the obligations that must be fulfilled, the healthier the company in terms of liquidity and debt responsibilities.

Financial ratios have an effect on investment risk with a coefficient of -0.230 and a p-value of $0.027(p<0.05)$, then the hypothesis is accepted, namely, that there is a negative and significant influence between financial ratios on investment risk. This means that the better the financial ratio of a company, the lower the investment risk. These results in line with research by Felicia (2019), Rizal (2016), Qadir (2018), Hariati and IMM (2012), which states that financial ratios have a significant effect on investment risk.

The relationship that occurs in this study is that the financial ratio variable has a negative relationship with investment risk; when the company experiences an increase in the profitability ratio, it will reduce the investment risk that will be accepted by investors. Likewise, if a company experiences an increase in the ratio of liquidity and solvency, the greater the ratio of assets owned to the liabilities of a company, the healthier and more liquid the company will be. This can have a positive impact on related companies, so that it can be a good consideration and reduce the investment risk that investors will face.

\section{b. Hypothesis Testing with Mediation}

Hypothesis testing with mediation is carried out using the online Sobel test. Table 6 the Sobel test results.

The results of the calculation of the Sobel test with a probability value of $0.535>0.05$, show that the indirect effect of financial ratio variables on Islamic stock returns through investment risk is proven to be insignificant. In other words, financial risk is not a mediating variable between financial ratios and Islamic stock returns. This result is in line with Firmansyah (2016) that states that investment risk does not mediate the effect of financial ratios on stock returns. 
The results of this study show that the investment risk inherent in stocks in the capital market is not a variable that determines that the variable financial ratios studied are strongly influenced by risk, therefore investors will pay more attention to the direct effect of financial ratios to consider investment and stock returns capital market.

\section{Conclusion}

Based on the results of data processing and discussion, the results of the hypothesis testing leads to the following observations. Investment risk has no effect on sharia stock returns; the level of investment risk as seen from the stock beta does not have an impact on the level of returns of Islamic stocks accepted by investors. Financial ratios have a positive and significant effect on Islamic stock returns - the better the financial ratio of a company, the bigger the increase in returns of Islamic stocks. Macroeconomics has no effect on sharia stock returns; the worse the macroeconomic factors in Indonesia are, the sharia stock returns will not necessarily experience a decline.

Financial ratios have a negative and significant effect on investment risk - the better the financial ratio of a company, the lower the investment risk. Macroeconomics has no effect on investment risk, meaning that the worse the macroeconomic situation will not necessarily trigger high investment risk. Investment risk is not able to be a mediating variable between the influence of financial and macroeconomic ratios on sharia stock returns, in expecting returns on Islamic stocks in JII investors only consider the financial ratio (company fundamentals) or economic conditions directly and do not consider the risks that will be accepted later.

\section{References}

Abbas, G. (2019). Return and volatility connectedness between stock markets and macroeconomic factors in the G-7 countries. Journal of Systems Science and Systems Engineering, 28(1), $1-36$.

Abi Nugroho, G., \& Hermuningsih, S. (2020). The Effect of Rupiah Exchange, Inflation And Interest Rate On The Return of Sub-Construction And Building Services Sector Companies In Indonesia Stock Exchange. DERIVATIF: Journal of Management, 14(1).

Al-Yahyaee, K. H. D. (2020). Do Islamic stocks outperform conventional stock sectors during normal and crisis periods? Extreme co-movements and portfolio management analysis. Pacific-Basin Finance Journal, 101385.

Andyani, K. W., \& Mustanda, I. K. (2018). The Influence of Micro and Macro Economic Variables on Stock Returns. E-Jurnal Manajemen Universitas Udayana, 7(4).

Ang, R. (1997). Smart Books of Indonesia Capital Stock. Jakarta, Indonesia: Mediasoft Indonesia.
Arif, A. d. (2020). The Effect of Return on Asset, Return on Equity And Debt To Equity Ratio on Return of Shares in Food And Beverage Subsectors in Indonesia Stock Exchange. Journal of Economic, Management, Business and Accounting, 8(1).

Artaya, M. (2014). The Effect of Macroeconomic Factors, Investment Risk and Financial Performance on Company Stock Returns on the Indonesia Stock Exchange. E-Journal of Economic and Business of Udayana University, 3(12), 689-701.

Artha, D. R. (2014). Fundamental, technical and macroeconomics analysis of share prices in the agricultural sector. Journal of Management and Entrepreneurship, 16(2), 175-184.

Aryanti, A., \& Mawardi, M. (2016). Effect of ROA, ROE, NPM and CR on Stock Returns in companies listed on the Jakarta Islamic Index (JII). I-Finance: a Research Journal on Islamic Finance, 2(2), 54-71.

bappenas.go.id. (2019). Indonesia on the Top Position of the Global Islamic Financial Market, Bambang as a Minister Receives the 2019 Global Islamic Finance Report Award. Retrieved from https://www.bappenas.go.id/

Dita, A. H., \& Murtaqi, I. (2014). The Effect of Net Profit Margin, Price to Book Value and Debt to Equity Ratio to Stock Return in the Indonesian Consumer Goods Industry. Journal of Business and Management, 3(3), 305-315.

Erari, A. (2014). Analysis of the Effect of Current Ratio, Debt To Equity Ratio, and Return On Assets on Stock Returns in Mining Companies on the Indonesia Stock Exchange. Journal of Business Management, 5(2), 174-191.

Erzad, A. M. (2017). The Effect of Financial Ratios Toward Sharia Stock Return In Jakarta Islamic Index (JII). Qudus International Journal of Islamic Studies, 5(1), 129-150.

Farhana, S., \& Adelina, Y. E. (2019). Value Relevance Of Sustainability Reporting In Indonesia. Journal of Multiparadigm Accounting, 10(3).

Farida, M., \& Darmawan, A. (2017). effect of risk of inflation, interest rate risk, foreign exchange risk and profitability on stock returns. Journal of Business Administration, 51(1), 49-57.

Felicia, N. E. (2019). The Effect of Current Ratio (Cr), Debt To Equity Ratio (Der), Return on Asset (Roa), Earnings Per Share (Eps) on Share Returns And Systematic Risk In Infrastructure Sector Companies, Securities, Indonesia Securities, Listed Transport -2018. Postgraduate Library.

Ferdinan, A. (2000). Structural Equation Modeling in Management Research. Semarang, Indonesia: Diponegoro University Publishing Agency.

Firmansyah, I. (2016). Determinants of Islamic stock returns with systematic risk as the mediating variable. Journal of Finance and Banking, 20(3), 358-368.

Habib, M., \& Islam, K. U. (2017). Impact of macroeconomic variables on islamic stock market returns: Evidence from NIFTY 50 Shariah Index. Journal of Commerce and Accounting Research, 6(1), 37.

Hariati, C., \& IMM, N. S. (2012). Correlation of rupiah exchange rate, interest rate, and profitability ratio to beta islamic stock. The Indonesian Accounting Review, 3(1), 99-106. 
Hernowo, A. (2020). Effect of Macro-Economic Variables on Share Return: An Empirical Study of Companies Listed on The Indonesia Stock Exchange 2007-2017. Indonesian Education University, Indonesia.

Hidayat, R. R. (2019). The Effect of Macroeconomics and Financial Performance on Systematic Risk and Stock Return (Study on Basic Industrial Companies and Chemical Listed on the Indonesia Stock Exchange, Period 2011-2015). Brawijaya University, Indonesia.

idx.co.id. (2018). Stock. Retrieved from https://www.idx.co.id/

Indiyani, P. S. (2020). Analysis of The Effect of Financial Ratios on The Return of Manufacturing Companies Registered In Indonesia Stock Exchange 2016-2018. Journal of Economics and Tourism, 15(1).

Indriastuti, A., \& Nafiah, Z. (2017). The Effect of Trading Volume, Exchange Rate and Market Risk on Stock Returns. Journal of STIE Semarang, 9(1), 57-66.

Jamaludin, N. (2017). Macroeconomic variables and stock market returns: Panel analysis from selected ASEAN countries. International Journal of Economics and Financial Issues, 7(1).

Kurniawan, A., \& Yusra, I. (2019). Do profitability and book value have an impact on stock returns ?: Empirical study on LQ45 companies.

Latifah, A. N. (2020). The Effect of Financial Ratios on Return of Shares With The Value of The Company as an Intervening Variables. Journal of Education and Economics, 9(1), 72-81.

Lee, J. W., \& Brahmasrene, T. (2020). An Exploration of Dynamic Relationships between Macroeconomic Variables and Stock Prices in Korea Revisited. Journal of Asian Finance, Economics and Business, 7(10), 23-34. https://doi.org/10.13106/ jafeb.2020.vol7.no10.023

Marito, B. C., \& Sjarif, A. D. (2020). The Impact of Current Ratio, Debt to Equity Ratio, Return on Assets, Dividend Yield, and Market Capitalization on Stock Return (Evidence from Listed Manufacturing Companies in Indonesia Stock Exchange). Scientific Journal of PPI-UKM, 7(1), 10-16.

Mawarni, C. P., \& Widiasmara, A. (2018). The Effect of the FED Rate, World Oil Price, BI Rate, Inflation and the Rupiah Exchange Rate on the Indonesian Islamic Stock Index (ISSI) for the 2011-2017 Period. Inventory: Journal of Accounting, 2(2), 281-297.

Mensi, W. (2017). Impact of macroeconomic factors and country risk ratings on GCC stock markets: Evidence from a dynamic panel threshold model with regime switching. Applied Economics, 49(13), 1255-1272.

Minto, W. (2016). Easy Fast Appropriate Use of Amos Tools In Applications (SEM): UPN "VETERAN" East Java.

Nguyen, T. N., Nguyen, D. T., \& Nguyen, V. N. (2020). The Impacts of Oil Price and Exchange Rate on Vietnamese Stock Market. Journal of Asian Finance, Economics and Business, 7(8), 143-150. https://doi.org/10.13106/jafeb.2020.vol7.no8.143
Nurhikmawaty, D. D. (2020). The Effect of Debt to Equity Ratio and Return on Equity on Stock Return with Dividend Policy as Intervening Variables in Subsectors Property and Real Estate on Indonesia Stock Exchange. International Journal of Multicultural and Multireligious Understanding, 7(7), 255-267.

Perkasa, R. S. (2019). The Effect of Macroeconomic Variables (Inflation, Interest Rate, Exchange, GDP and Amount of Currency) on Shares Return of Panin Dubai Syariah Through ROA as Intervening Variables For 2010-2018. IAIN SALTING.

Pratama, I. G. S., \& Idawati, I. A. A. (2019). The Effect of Financial Ratios on Stock Returns in Agricultural Companies on the Indonesia Stock Exchange. Wicaksana: Journal of Environment and Development, 3(1), 38-44.

Purbawangsa, I. B. A. (2020). The Effect of Financial Performance on Stock Return At Manufacturing Company of Indonesia Stock Exchange. Russian Journal of Agricultural and SocioEconomic Sciences, 1(97).

Qadir, Z. A. (2018). Analysis Effect of Macroeconomic Variables and Micro Economic Variables on Share Investment Risk. University of Merci Buena Jakarta, Indonesia.

Rahman, A. (2014). The Effect of Financial Performance on Stock Returns in Companies Listed in the Jakarta Islamic Index (JII) on the Indonesia Stock Exchange. Journal of STIE Semarang, 10(04).

Rizal, M. (2016). Analysis of the Effect of Profitability and Liquidity on Sharia Stock Returns with Investment Risk as an Intervening Variable.

Roslianti, R., \& Herlambang, L. (2015). The Effect of Financial Performance on Stock Returns (Study on Sharia Stock in the Manufacturing Sector Listed in the Indonesian Sharia Stock Index 2011-2012). Journal of Islamic Economics Theory and Applied, 1(7).

Singa, N. A. G., Nainggolan, B. R. M., \& Waruwu, E. (2020). The Effect of ROA, Investment Decisions, CR, TATO and Cash Flow on Stock Returns of Manufacturing Companies. Journal of Economic, Business and Accounting, 3(2), 292-299.

Suciati, N. H. D. The Effect of Financial Ratio and Firm Size on Stock Return in Property and Real Estate Companies Listed on the Indonesia Stock Exchange.

Suciningtias, S. A., \& Khoiroh, R. (2015). Analysis impact of macroeconomic variables on the Indonesian Islamic stock index (ISSI). Paper presented at the Conference in Business, Accounting, and Management (CBAM).

Supadi, D. B. P., \& Amin, M. N. (2016). Pengaruh faktor fundamental dan risiko sistematis terhadap return saham syariah. Media Riset Akuntansi, Auditing \& Informasi, 12(1), 23-44.

Suyati, S. (2016). The Effect of Inflation, Interest Rates and Rupiah / US Dollar Exchange Rates on the Return of Property Shares Listed on the Indonesia Stock Exchange. Serat Acitya, 4(3), 70. 
Tandelilin, E. (2010). Portfolios and Investments: Theory and applications. Jakarta, Indonesia: Kanisius.

Thampanya, N. D. (2020). Fundamental and behavioural determinants of stock return volatility in ASEAN-5 countries. Journal of International Financial Markets, Institutions and Money, 65, 101193.

Tran, Q. T., Nguyen, N. K. D., \& To, P. Q. A. (2020). Financial Ratios Affecting Disclosure Level in Interim Report of Vietnamese Listed Enterprises. Journal of Asian Finance, Economics and Business, 7(10), 43-50. https://doi.org/10.13106/jafeb.2020.vol7.no10.043
Wijaya, L. I. (2020). The Role of Dividend Catering Theory and Dividend Signaling Theory in the Indonesian Capital Market. University of Airlangga, Indonesia.

Yusfiarto, R. (2020). Micro Macro Economics Fundamental Factors and Indonesia Stock Exchange Return. EkBis: Jurnal Ekonomi Dan Bisnis, 3(1), 221-231.

Yusfiarto, R., \& Pambekti, G. T. (2020). Effect of Macroeconomic Variables on Jakarta Islamic Index: Evidence The Global Trade War Phenomenon. Media of Economy, 27(2), 119-132. 